\title{
HUBUNGAN CEMARAN BAKTERI Salmonella typhi PADA FESES ANAK TERHADAP PERSONAL HIGIENE DI KELURAHAN KAMPUNG MAKASSAR TIMUR KOTA TERNATE
}

\author{
Erpi Nurdin \\ Jurusan Analis Kesehatan; Poltekkes Kemenkes Ternate \\ Jl. Cempaka, Kel. Tanah Tinggi Barat Kota Ternate \\ erpinurdin@yahoo.com
}

\begin{abstract}
Abstrak
Cemaran bakteri Salmonella typhi pada feses sangat erat kaitannya dengan hygiene pribadi. Penularan penyakit ini hamper selalu terjadi melalui makanan dan minuman yang terkontaminasi, yang menyebabkan penyakit abdominalis. Infeksi bakteri Salmonella typhi diperkirakan angka insidensi di seluruh dunia terdapat sekitar 17 juta per tahundengan 600.000 orang meninggal. WHO memperkirakan 70\% kematianterjadi di Asia.Kampung Makassar merupakan kelurahan dengan sanitasi yang belum memadai. Penelitian ini bersifat komparatif dan bertujuan untuk mengetahui hubungan cemaran bakteri Salmonella typhi terhadap personal higiene anak di Kelurahan Kampung Makassar Kota Ternate.Teknik pengambilan sampel adalah secara non random dengan desain purposive sampling sebesar 40 orang. Sampel tersebut kemudian dibuat perlakuan untuk diidentifikasi Salmonella typhi dengan metode kultur feses. Dari hasil penelitian di peroleh hasil 17 sampel positif terdeteksi positif sebagai Salmonella typhi, dengan tingkat hygiene 3 buruk, 30 cukup baik, dan 7 baik. Berdasarkan hasil pengolahan data diperoleh $p$ value 0,037<0,05. Berdasarkan hasil penelitian dapat disimpulkan bahwa terdapat hubungan yang bermakna antara cemaran Salmonella typhi pada feses anak terhadap personal hygiene.
\end{abstract}

Kata Kunci : Salmonella typhi, personal hiegene, kultur feses

\section{Pendahuluan}

Demam tifoid atau thypus abdominalis adalah penyakit infeksi akut yang biasanya mengenai saluran pencernaan dengan gejala demam lebih dari 7 hari, gangguan pada saluran cerna dan gangguan kesadaran. Dalam masyarakat 2 penyakit ini dikenal dengan nama Tipes atau thypus. Penyakit ini disebabkan oleh Salmonella typhi dan hanya didapatkan pada manusia. Penularan penyakit ini hampir selalu terjadi melalui makanan dan minuman yang terkontaminasi (T.H.Rampengan, 2007).

Berdasarkan Profil Kesehatan Indonesia tahun 2009 jumlah kejadian demam tifoid dan paratifoid di Rumah Sakit adalah 80.850kasus pada penderita rawat inap dan 1.013 diantaranya meninggal dunia. Sedangkan pada tahun 2010 penderita demam tifoid dan paratifoid sejumlah 41.081 kasus pada penderita rawat inap dan jumlah pasien meninggal dunia sebanyak 276 jiwa (DepkesRI, 2010). Dalam Profil Kesehatan Provinsi Jawa Tengah tahun 2008 Demam Tifoid termasuk dalam kejadian luar biasa (KLB) dengan attack rate sebesar 0,37\% yang menyerang 4 kecamatan dengan jumlah 4 desa dan jumlah penderita 51 jiwa. Pada tahun 2009 terjadi peningkatan jumlah penderita Demam Tifoid sebesar 150 jiwa yang menyerang 3 kecamatan dan jumlah 3 desa dengan attack rate sebesar 2,69\%. Tahun 2010 kasus KLB demam Tifoid kembali terjadi dengan attack rate sebesar 1,36\% yang menyerang 1 kecamatan dengan 1 desa dan jumlah penderita 26 jiwa (DepkesRI, 2010). 
Data yang diperoleh dari Dinas Kesehatan

Kota Ternate menunjukkan bahwa kasus Demam Tifoid selalu terjadi setiap bulannya dan merupakan penyakit yang sering terjadi dalam jumlah yang besar. Rekapitulasi bulanan data 4 kesakitan Demam Tifoid tingkat puskesmas se-Kota Ternate kasus Demam Tifoid mengalami peningkatan dari tahun ke tahun, yaitu pada tahun 2003 sebesar 81 kasus, kemudian mengalami peningkatan kasus pada tahun 2004 yaitu sebanyak 87 kasus, dan pada tahun 2015 mengalami peningkatan sebanyak 112 kasus. Sedangkan pada tahun 2016 sedikit mengalami penurunan yaitu sebanyak 64 penderita. Angka kasus Demam Tifoid tertinggi di Kota Semarang tahun 2016 berada di Puskesmas Kalumpang. Angka kasus Demam Tifoid di Puskesmas Kalumpangtercatat cukup tinggi.

Demam tifoid atau tifus abdominalis banyak ditemukan dalam kehidupan masyarakat Kota Ternate. Penyakit ini sangat erat kaitannya dengan higiene pribadi dan sanitasi lingkungan seperti higiene perorangan yang rendah, lingkungan yang kumuh, kebersihan tempat-tempat umum (rumah makan, restoran) yang kurang serta perilaku masyarakat yang tidak mendukung untuk hidup sehat. Seiring dengan terjadinya krisis ekonomi yang berkepanjangan akan menimbulkan peningkatan kasus-kasus penyakit menular, termasuk tifoid ini (Depkes RI, 2010).

Dari hasil survei PHBS yang dilakukan Puskesmas Kalumpang tahun 2015, jumlah rumah yang ada sebanyak 511 unit sedangkan kategori rumah yang memenuhi syarat kesehatan sebanyak 243 rumah (49\%). PHBS tatanan rumah tangga merupakan tatanan yang mempunyai daya ungkit paling besar terhadap perilaku kesehatan masyarakat yang merupakan salah satu faktor pendukung terjadinya penyakit atau penyebab kematian.

Berdasarkan wawancara yang dilakukan langsung ke tiap-tiap rumah pada tanggal 01-03 Juni 2017 terhadap 15 responden yang pernah menderita demam tifoid pada tahun 2016 di wilayah kerja Puskesmas Kalumpang mengenai sanitasi lingkungan dan higiene perorangan diketahui yaitu sarana air bersih.

\section{Metode}

Alat dan bahan yang digunakan pada penelitian ini yaitu Pot penampung feses steril, Medium Salmonella shigella Agar (SSA), Medium Triple Sugar Iron Agar (TSIA), Lampu spirtus, Spirtus, Mikroskop, Tabung steril, Objek gelas dan kaca penutup, Swab steril, Carry and Blair, Selenite broth, Gentian Violet, Ose bulaT, Ose lurus, Lugol, Etanol 96\%, Fuchsin, Minyak emersi

\section{Hasil dan Pembahasan}

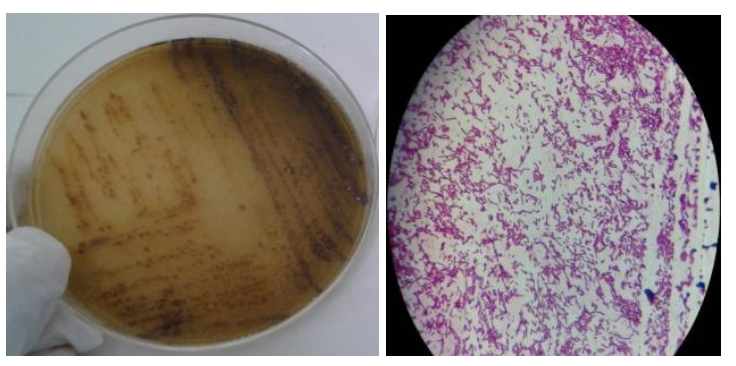

Gambar 1. Koloni Salmonella typhi pada SSA dan hasil gram staining (1000x)

Tabel 1. Distribusi dan Frekuensi Salmonella typhi terhadap personal hiegen anak

Higenitas Kultur S. typhi Total




\begin{tabular}{lccc}
\hline & Negatif & Positif & \\
\hline Buruk & 1 & 2 & 3 \\
\hline Cukup Baik & 15 & 15 & 30 \\
\hline Baik & 7 & 0 & 7 \\
\hline Total & 23 & 17 & 40 \\
\hline
\end{tabular}

(Sumber : Data Primer, 2017)

Tabel 2. Pengukuran hubungan cemaran Salmonella typhi terhadap personal hygiene melalui uji Corelasi Contigens

\begin{tabular}{|c|c|c|c|c|c|}
\hline \multicolumn{6}{|c|}{ Symmetric Measures } \\
\hline & & Value & $\begin{array}{c}\text { ymp. } \\
\text { Std. } \\
\text { Error } \\
\text { a }\end{array}$ & $\begin{array}{r}\text { Approx } \\
. T^{\mathrm{b}}\end{array}$ & $\begin{array}{l}\text { Approx. } \\
\text { Sig. }\end{array}$ \\
\hline $\begin{array}{l}\text { Nominal } \\
\text { by } \\
\text { Nominal }\end{array}$ & $\begin{array}{l}\text { Contingency } \\
\text { Coefficient }\end{array}$ & .376 & & & .037 \\
\hline $\begin{array}{l}\text { Interval } \\
\text { by } \\
\text { Interval }\end{array}$ & Pearson's R & -.382 & .109 & -2.548 & $.015^{c}$ \\
\hline $\begin{array}{l}\text { Ordinal } \\
\text { by } \\
\text { Ordinal }\end{array}$ & $\begin{array}{l}\text { Spearman } \\
\text { Correlation }\end{array}$ & -.388 & .107 & -2.594 & $.013^{c}$ \\
\hline $\mathrm{N}$ of Valic & Cases & 40 & & & \\
\hline
\end{tabular}

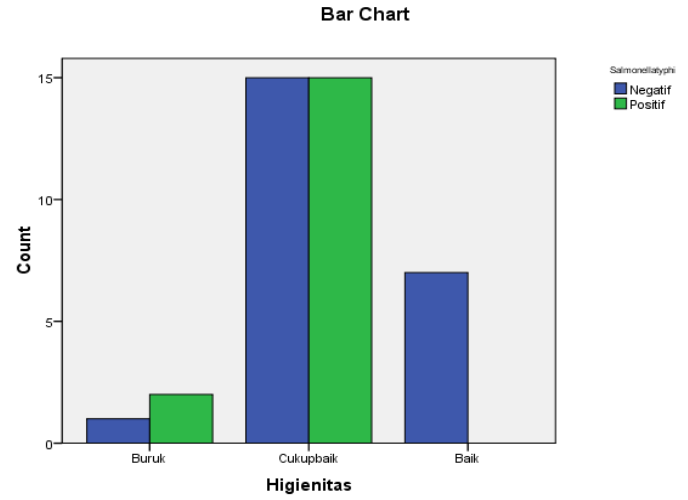

Gambar 2. Diagram simetris cemaran Salmonella typhi terhadap tingkat personal hygiene (Sumber:

Data Primer, 2017)

Kelurahan Kampung Makassar Timur, merupakan kawasan dengan sanitasi yang kurang baik. Terlihat tingginya kasus kecacingan, sesuai dengan penelitian Noni Albaar tahun 2016. Menurut pengamatan peneliti, kawasan kampong Makassar masih terlihat keadaan yang belum mencerminkan Perilaku Hidup Sehat.
Berdasarkan hasil penelitian dari 40 sampel yang diperiksa terdapat 2 sampel positif Salmonella typhi dengan sanitasi buruk, 15 sampel positif dengan sanitasi cukup baik, dan tidak terdapat sampel positif dengan sanitasi baik.

Data penelitian di olah dengan menggunakan uji corelasi Contigens dengan variabel nominal untuk pengukuran Salmonella typhi, dan variable ordinal tingkat personal hygiene. Dari hasil pengolahan data di peroleh tingkat kemaknaan hubungan 0,037.

\section{Simpulan dan Saran}

Berdasarkan penelitian yang telah dilaksanakan, maka diperoleh kesimpulan sebagai berikut :

1. Terdapat 17 sampel responden terdeteksi positif Salmonella typhi, dengan tingkat hygiene 3 buruk, 30 cukup baik , dan 7 baik.

2. Berdasarkan hasil pengolahan data diperoleh $p$ value $0,037<0,05$ yang menunjukkan bahwa terdapat hubungan yang bermakna antara cemaran Salmonella typhi pada feses anak terhadap personal hygiene.

Berdasarkan kesimpulan dari penelitian ini, maka perlu disarankan adalah :

1. Diperlukan penelitian lanjutan pada tahap kultur dan molekuler

2. Kepada Dinas Kesehatan Kota Ternate untuk melakukan pemeriksaan berkelanjutan, melakukan tahap pengobatan dan konseling tentang pencegahan infeksi penyakit akibat bakteri Salmonella typhi 


\section{Ucapan Terima Kasih}

Terima kasih disampaikan kepada Poltekkes Kemenkes Ternate yang telah mendanai keberlangsungan jurnal ini. Atau ucapan terima kasih terutama ditujukan kepada pemberi dana penelitian atau donatur. Ucapan terima kasih dapat juga disampaikan kepada pihak-pihak yang membantu pelaksanaan penelitian.

\section{Daftar Pustaka}

Akiko.Kamata, 2009. Guidance on regulations for the transport of infectious substances2009-

2010.http://www.who.int/csr/resources/pu blications/

Bergey's, 2000. Slamonella typhi menurut Garrity dalam "Bergey's Manual of Systematic Bacteriology".

biosafety/WHO.HSEEPR_2008_10.pdf. Diakses tanggal 22 September 2017.

biosafety/WHO_HSE_EPR_2008_10.pdf.

Diakses tanggal 22 September 2017.

Buchnan, R.E. dan N.E Gibbons., 1974.Bergey's Mannal of Determination Bacteriology 8 th Edition. The williams dan Walkins Company/Baltimore. USA.

Depkes RI, 2010. Laporan Demam Tifoid. Jakarta

Entjang, I., 2003. Mikrobiologi Dan Parasitologi Untuk Akademi Keperawatan. PT Citra Aditya Bakti. Bandung.

Ferri, F.F., 2004. Clinical Advisor Instant Diagnosis and Treatment. Mosby, USA; 885.
Hatta M, Heerkens E,Smits HL. 2007.Detection Of Salmonella typhi by Nested Polymerase Chain Reaction In Blood, Urine, and Stool Samples. Am J Trop Med Hyg. hal.139-143.

Holme, D. J., Hazel, P. 1993. Analytical Biochemistry. Longman Scientific and Technical. England.

Juwono R, 2008. Demam tifoid dalam buku ajar ilmu penyakit dalam. Edisi3. Pusat Penerbitan Departemen Ilmu Penyakit Dalam FK UI. hal.436

Karsinah, Lucky, H.M., Suharto, dan Mardiastuti, H. W., 1993. Enterobacteriaceae, Batang Negative .Buku ajar Mikrobiologi Kedokteran. Bina Rupa Aksara. Jakarta. hal. 154-190.

Nurdin, Erpi., 2011. Pengukuran Kemampuan Ekstraksi DNA dengan Menggunakan Diatom Kering dari Berbagai Perlakuan Suhu secara Teknik Polimerase Chain Reaction (PCR). Skripsi. Universitas Hasanuddin. Makassar.

Rampengan, T.H., dan Laurentz, I.R., 2007.Penyakit Infeksi Tropik pada Anak. EGC. Jakarta. hal. 52-73.

Ryadi, Slamet.,1984. Pencemaran Air / Seri Lingkungan, dasar-Dasar dan Pokok-Pokok Penanggulangan.Surabaya; Penerbit Karya Anda.

Simanjuntak, CH., 2009. Masalah Demam Tifoid di Indonesia. Cermin Dunia Kedokteran No. 60. hal. 31-34.

WHO, 2009. Guidance on regulations for the transport of infectious substances2009-2010. http://www.who.int/csr/ resources/publications/ 